\author{
Sankov, P., Tkach, N., Dikarev, K., Blyzniuk, A., and Hvadzhaia, B. \\ Prydniprovska State Academy of Civil Engineering and Architecture, \\ 24a, Chernyshevskogo St., Dnipro, 49005, Ukraine, \\ +380 5624523 72, +380 56247 0788, postmaster@pgasa.dp.ua
}

\title{
EFFECT OF MOTOR TRANSPORT ON THE WORKING PLACES IN THE SERVICE INFRASTRUCTURE (BY NOISE FACTOR AND URBAN AIR POLLUTION IN THE CITY CENTER OF DNIPRO)
}

\begin{abstract}
Introduction. The article deals with the main provisions concerning the implementation of the constitutional right of employees on the protection of their life and health in the process of labor activity, on appropriate, safe and healthy working conditions, regulation of the relationship between the employer and the employee on safety and health issues, the working environment and the establishment of a unified procedure for the organization of labor protection in Ukraine, with the competent state authorities involved.

Problem Statement. The paper presents the results of problems analysis related to the development of modern urban center as a service infrastructure network taking into account the work safety at workplaces.

Purpose. To provide the service infrastructure employees with high-quality and safe working conditions (in terms of noise factor and air pollution by exhaust gases from motor vehicles along D. Yavornytskyi Avenue) in the downtown of the Dnipro city.

Materials and Methods. Information on the noise and air pollution from motor vehicles and the number of workplaces within the studied territory has been obtained from field observations.

Results. The noise pollution in 2 meters from the first echelon building facades on $D$. Yavornytskyi Avenue varies from $72 \mathrm{dBA}$ to $75 \mathrm{dBA}$. The concentration of exhaust gases ranges from 15 to $35 \mathrm{mg} / \mathrm{m}^{3}$. It has been established that in the city center, there are $6000 \mathrm{~m}^{2}$ commercial space of public and social and infrastructure, where 330 employees of various occupations are working.

Conclusions. The dynamics of changes in the traffic load on D. Yavornytskyi Avenue from 2011 through 2017 has been studied. The equivalent noise level and the exhaust gas concentration CCO at work places have been established to exceed the norm by $9-19 \mathrm{dBA}$ and by $15-30 \mathrm{mg} / \mathrm{m}^{3}$, respectively.
\end{abstract}

Keywords: public city center, traffic load, service facilities, and workplaces.

The changes taking place in Ukraine in the field of urbanization and development of transport, as well as a significant growth in traffic load on roads of modern cities and, above all, growing demands of society for living standards, quality and safety of life (QSL) make us pay much more attention to adequate organization of service infrastructure, harmonious coexistence and functional purpose of its components. In this context,

(c) SANKOV, P., TKACH, N., DIKAREV, K., BLYZNIUK, A., and HVADZHAIA, B., 2018 the safety of workplaces in service infrastructure shall be properly secured.

Modern theory of urban planning refers downtowns to the non-obligatorily attended destinations [1-6] which attract people to cultural, service, trade, and recreation infrastructure. It does not take into account the fact that these infrastructure facilities also employ people who have right to workplace of proper quality.

The urban planning issues have been discussed in many researches that deal with trends in the development of city downtown and district cen- 
ters [1], the optimal arrangement of city centers and districts, the connection between them, and the development of urban networks in Britain taking into account all infrastructure features, in particular, the public services [2]. To make design calculations for urban planning based only on the city population has been justified to be inadvisable. It is necessary to study and to take into account other components of the general issues and tasks of the city as a dynamically developing and needing to be improved structure [3]. Also, polycentrism of cities with necessary comprehensive consideration of all components of city life [4-6] has been discussed in detail.

In order to prevent material social and economic losses caused by improper use of valuable territories (downtowns) and to avoid in the future serious problems with traffic, public transport, safety and quality of life, which many large cities have faced, it is necessary to immediately develop prospective plans for rearrangement of city downtowns and to start their gradual implementation as it has been proposed for Moscow [7]. The ultimate social and economic effect depends mainly on the proper functional spatial model and principles of transformations rather than on the quality of separate buildings or their current use. In the Dnipro City, the first floors of the $1^{\text {st }}$ echelon buildings adjacent to the main road artery, D. Yavornytskyi Avenue, are occupied by social infrastructure facilities, pharmacies, bars, cafes, restaurants, bank outlets, etc. The traffic moving along the Avenue causes an essential increase in noise and pollutes the adjacent territories with exhaust gases. In opinion of all government bodies and urban planners, the mentioned territory is referred to the urban area. At the same time, the mentioned infrastructure facilities require more well-balanced approach to these territories in terms of labor safety at nonindustrial workplaces. Therefore, the problems discussed in this research are relevant and aim at innovation approach to address them.

The purpose is to evaluate quality and safety of workplaces (working conditions) of service infra- structure employees in terms of noise factor and air pollution by exhaust gases from motor vehicles moving along Dmytro Yavornytskyi Avenue in the downtown of the Dnipro city.

The objectives of research are as follows:

+ To measure the traffic load on the main road artery of the Dnipro City (D. Yavornytskyi Ave.);

+ To measure the noise factor and pollution with exhaust gases for the $1^{\text {st }}$ echelon buildings located along D. Yavornytskyi Avenue;

+ To carry out a field survey in order to determine the number of workplaces on the studied area.

Partly, the objectives have been fulfilled in [8-12], therefore, this research includes previously obtained results.

Contemporary transport, its quantitative and qualitative development, in particular, an increase in the number of private motor vehicles affect the quality of environment, especially, in the downtown. Measures towards reducing number of road accidents due to improvement of traffic management while keeping the existing structure and road schemes has a very weak effect. The use of technical improvements for reducing noise factor and exhaust gas pollution emitted by vehicles also may be not sufficiently effective. A radical measure to prevent adverse effects of motorization is revision of old principles of traffic and built-up area schemes formation. It is necessary to separate a large space to be used exclusively or mainly for the pedestrian traffic from the space used exclusively or mainly for the motor traffic. The transit traffic should bypass the downtown. This problem has been discussed in detail in [13].

It is desirable that inside the downtown, the traffic management is based on pedestrian traffic only. The territory shall be divided into separate zones: exclusively pedestrian traffic, dominant pedestrian traffic, dominant motor traffic, exclusively motor traffic.

The size of downtown, which depends, on the one hand, on the needs of society in a certain type and quantity of services and the existing model of the service infrastructure and, on the other hand, on the economic policy and opportunities, is also 


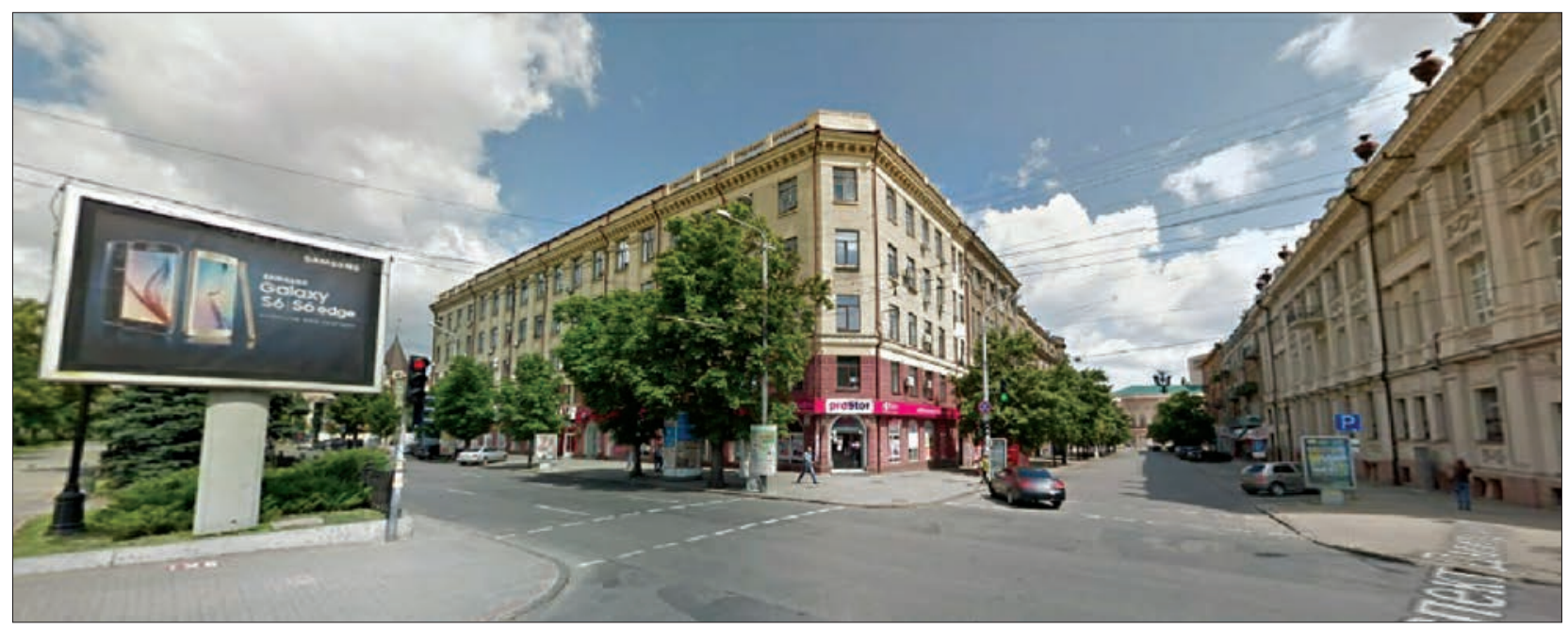

Fig. 1. Intersection of D. Yavornytskyi Ave. and Voskresenska St. (photo)

directly limited by the availability of transport and parking facilities. Due to growing social needs, the number of potential visitors to the downtown constantly increases. This opinion is shared by Kharkiv architect and urbanist Oleg Drozdov [14].

While arranging commercial and administrative facilities it is necessary to take into consideration the pedestrian traffic system that influences the district value in terms of transport. Map of district value in terms of transport can be used to control the correctness of planning of the city transport system (including, pedestrian path systems) and the efficiency of service infrastructure facilities arrangement. In 2011, within the framework of this objective the authors carried out a survey «design of noise map of street and roads network of Dnipropetrovsk City» [11]. Table 1 shows selected results of motor traffic intensity survey and calculations of carbon mono-oxide concentration $\left(\mathrm{C}_{\mathrm{CO}}\right)$ on the carriageway and equivalent noise level $\left(\mathrm{L}_{\text {Аекв }}\right)$ at a distance of $2 \mathrm{~m}$ from the $1^{\text {st }}$ echelon building façades in 2011 and reference values in 2017. The equivalent noise levels are measured by instrumental methods. Carbon mono-oxide concentration $\left(\mathrm{C}_{\mathrm{CO}}\right)$ is calculated and map of exhaust gas pollution is built based on the method developed by PSACEA [12].
Fig. 1 features a picture of D. Yavornytskyi Ave. and Voskresenska St. Intersection; Fig. 2 shows a map of exhaust gas pollution caused by motor traffic moving along D. Yavornytskyi Ave. and Voskresenska St. for the $1^{\text {st }}$ echelon buildings.

According to GOST 12.1.005 [15], air pollution with carbon oxide belongs to the $4^{\text {th }}$ class danger; its maximum permissible concentration must not exceed $20 \mathrm{mg} / \mathrm{m}^{3}$ within working area. This pollution shall be monitored quarterly. Practically, no measurements have been done in the premises of service infrastructure facilities mentioned in this research. Fig. 2 shows that carbon oxide concentration on the facades of $1^{\text {st }}$ echelon building reaches $15-35 \mathrm{mg} / \mathrm{m}^{3}$. The majority of premises is not equipped with forced air circulation systems, which is evidenced by external air conditioning units on the building facades (Fig. 3). The expected carbon oxide pollution inside the premises can reach $35-50 \mathrm{mg} / \mathrm{m}^{3}$, which exceeds the norm by $15-30 \mathrm{mg} / \mathrm{m}^{3}$.

The analysis of noise level on the $1^{\text {st }}$ echelon building facades in control point 5 (Table 1) has shown that the existing norms [16] are exceeded by $19 \mathrm{dBA}$ (for the whole studied area an excess of the permissible noise level varies within 14$20 \mathrm{dBA})$. In the premises of studied buildings, whe- 


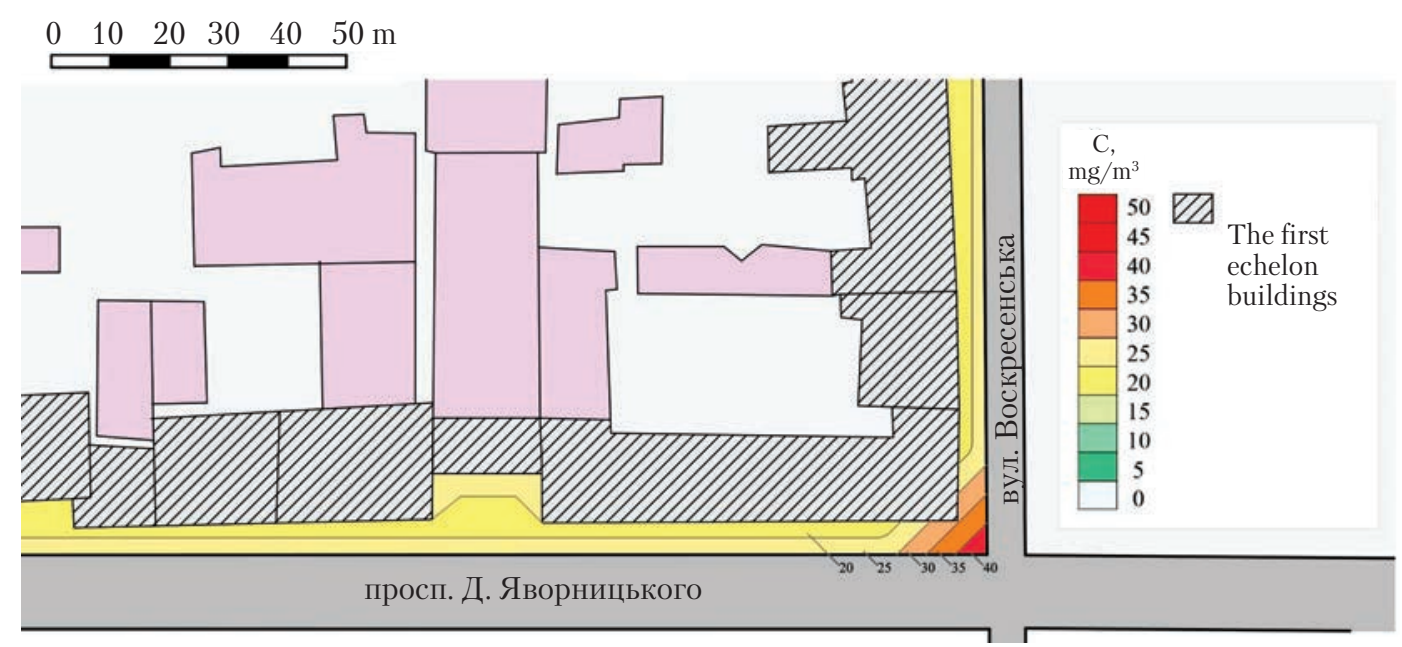

Fig. 2. Map of tailpipe pollution (D. Yavornytskyi Ave. and Voskresenska St.); the first echelon buildings

re service infrastructure facilities located, the noise level at workplaces exceeds the norm (50-60 dBA), by $9-19 \mathrm{dBA}$. The noise pollution inside the premises depends on several factors. In the case of sound insulation of windows (doors) in the ventilation mode (as mentioned above, the studied premises have no forced ventilation systems), the noise level decreases by $10 \mathrm{dBA}$, while if sound waves propagate from open space to closed one, the noise level increases by $3-5 \mathrm{dBA}$ due to wave reflection from internal walls.

To fulfill the last objective of this research, a field count of workplaces in the downtown of Dnipro City has been done. The calculations have been made for the $1^{\text {st }}$ echelon buildings located along D. Yavornytskyi Ave., from Barykadna St. to Andrii Fabr St. The average number of floors amounts to 5. In $160000 \mathrm{~m}^{2}$ studied area, there are many various social and service facilities occupying $6000 \mathrm{~m}^{2}$ and employing nearly 330 staff. It has been established that a workplace in the premises of service infrastructure facilities in the downtown of Dnipro City occupies about $18 \mathrm{~m}^{2}$. The linear density of workplaces makes up almost $10 \mathrm{~m}$ per a workplace. The preliminary surveys of adverse effects of noise pollution on employees are presented in $[17,18]$. The results given herein will be used in further developments in urban planning in terms of motor and pedestrian traffic organization and arrangement of service infrastructure facilities within the $1^{\text {st }}$ echelon buildings of the downtown. These developments will

Selected Results of Traffic Intensity Survey and Calculations

of Carbon Mono-Oxide Concentration $\left(\mathrm{C}_{\mathrm{CO}}\right)$ on the Carriageway and Equivalent Noise Level $\left(\mathrm{L}_{\text {Аекв }}\right)$ at a Distance of $2 \mathrm{~m}$ from the $1^{\text {st }}$ Echelon Building Façades

\begin{tabular}{|c|c|c|c|c|c|c|c|c|c|c|}
\hline \multirow{2}{*}{$\begin{array}{l}\text { Control } \\
\text { point }\end{array}$} & \multirow{2}{*}{$\begin{array}{l}\text { Area surveyed } \\
\text { (year of survey) }\end{array}$} & \multicolumn{5}{|c|}{ Traffic intensity } & \multirow{2}{*}{$\begin{array}{c}\text { Average speed } \\
\text { of traffic flow, } \\
\mathrm{km} / \mathrm{h}\end{array}$} & \multirow{2}{*}{$\begin{array}{c}\text { Street } \\
\text { width, m }\end{array}$} & \multirow{2}{*}{$\begin{array}{c}\mathrm{CO} \\
\text { concentration, } \\
\mathrm{mg} / \mathrm{m}^{3}\end{array}$} & \multirow{2}{*}{$\begin{array}{l}\mathrm{L}_{\text {Аекв }}, \\
\mathrm{dBA}\end{array}$} \\
\hline & & $\mathrm{N}$ & $\mathrm{N}_{J \mathrm{I}}$ & $\mathrm{N}_{\mathrm{B}}^{\mathrm{K}}$ & $\mathrm{N}_{\mathrm{B}}^{\mathrm{A}}$ & $\mathrm{N}_{\mathrm{B}}, \%$ & & & & \\
\hline 5 & $\begin{array}{l}\text { Karl Marx Ave. near the Main } \\
\text { Post Office (2011) }\end{array}$ & 1213 & 1003 & 110 & 100 & 20 & 50 & 54 & 31.12 & 73.1 \\
\hline 5 & $\begin{array}{l}\text { Yavornytskyi Ave. near the } \\
\text { Main Post Office (2017) }\end{array}$ & 1418 & 1130 & 148 & 140 & 20 & 50 & 54 & 34.07 & 74.0 \\
\hline
\end{tabular}




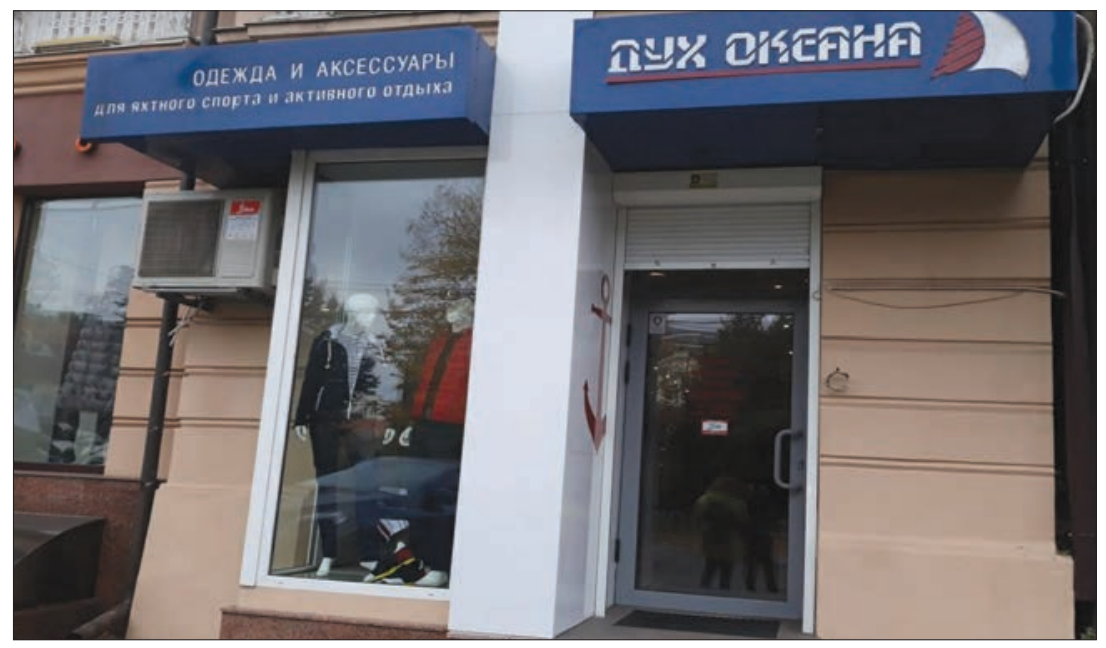

Fig. 3. Outdoor air conditioning units on building facades: $a$ - retail outlet with outdoor air conditioning unit; $b-$ Bank outlets with outdoor air conditioning units
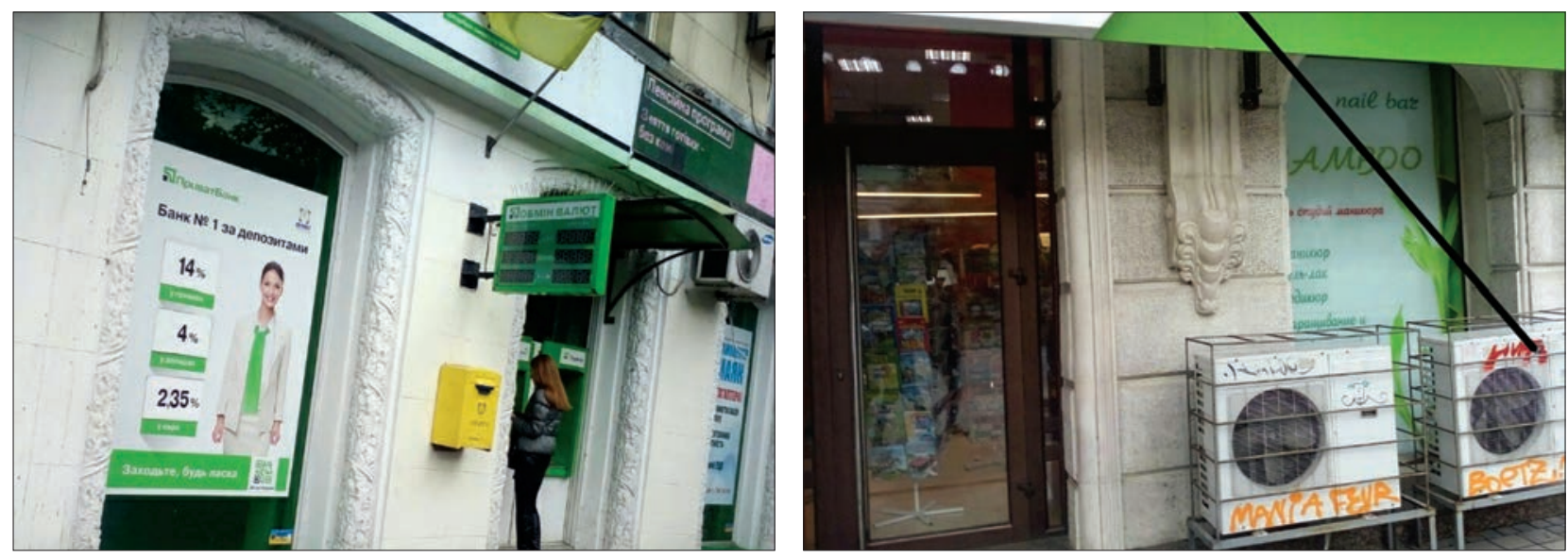

$b$

facilitate improving quality and safety of city population life as a whole.

The results presented in this research have a scientific and practical significance.

Dynamics of changes in traffic load on the main road artery, D. Yavornytskyi Ave., from 2011 to 2017 have been studied. As of today, the general traffic intensity has grown from 1213 vehicles/ hour to 1418 vehicles/hour.

The noise level and exhaust gas pollution for the $1^{\text {st }}$ echelon buildings at D. Yavornytskyi Ave. have been quantified. The equivalent noise level increased from $73.1 \mathrm{dBA}$ to $74.0 \mathrm{dBA}$, whereas the concentration $\mathrm{C}_{\mathrm{CO}}$ grew from $31.12 \mathrm{mg} / \mathrm{m}^{3}$ to $34.07 \mathrm{mg} / \mathrm{m}^{3}$.
A field count of workplaces in the downtown of Dnipro City has been done. In $160000 \mathrm{~m}^{2}$ studied area, there are many various social and service facilities occupying $6000 \mathrm{~m}^{2}$ and employing a nearly 330 staff. It has been established that a workplace in the premises of service infrastructure facilities in the downtown of Dnipro City occupies about $18 \mathrm{~m}^{2}$; the linear density of workplaces makes up almost $10 \mathrm{~m}$ per a workplace.

For the first time, the noise level at a distance of $2 \mathrm{~m}$ from the $1^{\text {st }}$ echelon building facades on D. Yavornytskyi Ave. has been established to exceed the existing norm by 15-19 dBA, while the excessive concentration of exhaust gases on the facades varies from $15 \mathrm{mg} / \mathrm{m}^{3}$ to $35 \mathrm{mg} / \mathrm{m}^{3}$; if the gases come 
into the premise from outside the concentration can exceed the norm at workplaces by $15-30 \mathrm{mg} / \mathrm{m}^{3}$.

One of the tasks for further research is to analyze the main categories of workplaces and harmful factors, as well as their norming, which affect the employees in the area of city downtown. The results of such studies are extremely important for reviewing and improving the regulations and standards of Ukraine in the field of labor protection and sanitary regulation.

\section{REFERENCES}

1. Batty, M. (2001). Polynucleated urban landscapes. Urban Stud., 38(4), 635-655 [in English].

2. De Goei, B., Burger, M. J., Van Oort, F. G., Kitson, M. (2010). Functional Polycentrism and Urban Network Development in the Greater South East. United Kingdom: Evidence from Commuting Patterns, 1981-2001. Reg. Stud., 44(9), $1149-1170$ [in English].

3. Arcaute, E., Hatna, E., Ferguson, P., Youn, H., Johansson, A., Batty, M. (2014). Constructing cities, deconstructing scaling laws.J. R. Soc. Interface, 12(102), 20140745-20140745 [in English].

4. Batty, M. (2015). Competition in the Built Environment: Scaling Laws for Cities, Neighbourhoods and Buildings. Nexus Netw.J., 17(3), 831-850 [in English].

5. Pomorov, S. B., Zhukovskiy, R. S. (2015). Retrospektiva razvitiya gorodskogo politsentrizma i teoreticheskih predstavleniy o nem. Teoriya arhitekturyi (Theory of architecture). URL: http://archvuz.ru/2015_4/3 (Last accessed: 10.11.2017).

6. Novikov, A., Kotov, E., Goncharov, R., Goncharov R., Nikogosyan K. (2016). Moskva: kurs na politsentrichnost. Otsenka effektov gradostroitelnyih proektov na politsentricheskoe razvitie Moskvyi. Moskva: NIU VSHE [in Russian].

7. Sankov, P. N., Tkach, N. A. (2017, January). Quality in designing and maintenance of ecological safety of modern cities. In: The collection of articles of the «The development of science in the $21^{\text {st }}$ century». Kharkiv.

8. Sankov, P. N., Gilyov, V. V., Makarova, V. N. (2016). Ekologicheskaya bezopasnosnost selitebnyih zon kak sostalyayuschaya kachestva gorodskoy sredyi. Nauchnoe obozrenie. Tehnicheskie nauki (Scientific review. Technical science), 4, 60-76 [in Russian].

9. Sankov, P. N. (2016). Organizatsii bezopassnyih usloviy truda I otdyiha grazhdan po factoru shumovogo zagryazneniya. Stroitelstvo, materialovedenie, mashinostroenie. Starodubovskie chteniya. (Construction, material science, mechanical engineering. Proceedings in memory of Starodubov 2016). 90, 158-163 [in Russian].

10. Sankov, P. M., Tkach, N. O., Nazha, P. M., Blyzniuk, A. M. (2017). Information on the general condition of urban noise pollution. International journal of applied and fundamental research, 4. URL: www.science-sd.com/472-25324 (Last accessed: 18.10.2017) [in English].

11. Zvit. Konkurs proektiv «Molod Dnipropetrovska - ridnomu mistu» Proektuvannya karti shumu vulichno-dorozhnoyi merezhi mista Dnipropetrovska. PDABA-2011, Dnipropetrovsk [in Ukrainian].

12. Eliseeva D. V. (Ed.). (2014). Vliyanie tehnogennyih faktorov na ekologiyu. Novosibirsk: «SibAK» [in Russian].

13 Sankov, P. N. (2017). Uchet tranzitnogo dvizheniya avtotransporta po magistralyam goroda s tselyu povyisheniya ekologicheskoy bezopasnosti prozhivaniya naseleniya. Stroitelstvo, materialovedenie, mashinostroenie. Starodubovskie chteniya (Construction, material science, mechanical engineering. Proceedings in memory of Starodubov 2017), 96, 128-132 [in Russian].

14 Drozdov, O. It's time to produce the city idea. URL: http://www.mediaport.ua/oleg-drozdov-pora-proizvoditideyu-goroda (Last accessed: 10.11.2017) [in Russian].

15. GOST 12.1.005. Vozduh rabochey zonyi. Obschie sanitarno-gigienicheskie trebovaniya.

16. DSN 3.3.6.037-99. Sanitarni normi virobnichogo shumu, ultrazvuku ta infrazvuku. K.: Ministerstvo ohoroni zdorov'ya Ukrayini, 1999, 35 [in Ukrainian].

17. Sankov, P. M., Tkach, N. O., Gorb, A. V., Mikheenko, Yu. Yu., Yakovenko, A. V. (2015). Architectural and spatial organization of safe working conditions on the noise factor in the territories of industrial enterprises and housing development by analyzing the noise regime from factories for the production of prefabricated reinforced concrete. In: XI International scientific and practical conference. Science and civilization. Sheffield, 2015 [in Ukrainian].

18. Sankov, P. N., Tkach, N. A., Nesterenko, S. V., Kalmyikova, E. A. (2016). Analiz shumozaschitnyih mer po obespecheniyu bezopasnosti na rabochih mestah shumnyih proizvodstv i prilegayuschih $\mathrm{k}$ nim territoriyah. Mezhdunarodnyiy nauchnyiy zhurnal: sbornik nauchnyih trudor, 5. URL: http://www.inter-nauka.com/issues/2016/5/1110 (Last accessed: 10.11.2017) [in Russian]. 
19. Peter Sankov, Nataliia Tkach, Ivan Trifonov, Illia Iliev and Alina Blyzniuk. (2017). Residential Environmental and Ecological Safety of Person. IJISET - International Journal of Innovative Science, Engineering \& Technology, 4(4), 278-281. URL: http://ijiset.com/vol4/v4s4/IJISET_V4_I04_31.pdf (Last accessed: 10.11.2017) [in English].

20. Sankov, P., Trifonov, I., Tkach, N., Hilov, V., Bakharev, V., Tretyakov, O., Nesterenko, S. (2017). Development of the method of evaluation the level of environmental safety of housing accommodation and its approbation. Eastern-European Journal of Enterprise Technologies, 4/10(88), 61-69, 79-80 [in English].

Received 20.11.17

\author{
П.М. Саньков, Н.О. Ткач, К.Б. Дікарев, \\ А.М. Близнюк, Б. Д. Гваджаіа \\ ДВНЗ «Придніпровська державна академія будівництва та архітектури», \\ вул. Чернишевського, 24а, Дніпро, 49005, Україна, \\ +380 56452 372, +380562470788, postmaster@pgasa.dp.ua \\ ВПЛИВ АВТОТРАНСПОРТУ НА РОБОЧІ МІСЦЯ \\ В МЕРЕЖІ УСТАНОВ ОБСЛУГОВУВАННЯ \\ (ЗА ФАКТОРОМ ШУМУ Й ЗАГАЗОВАНОСТІ \\ В ЦЕНТРІ МІСТА ДНІПРО)
}

Вступ. Розглянуто основні положення щодо реалізації конституційного права працівників на охорону їх життя та здоров’я у процесі трудової діяльності, на належні та безпечні умови праці, а також питання щодо регуляції за участю відповідних органів державної влади відносин між роботодавцем і працівником з питань безпеки, гігієни праці та виробничого середовища й встановлення єдиного порядку організації охорони праці в Україні.

Проблематика. Аналіз проблем розвитку сучасного громадського центру як мережі установ обслуговування з урахуванням стану безпеки праці на робочих місцях.

Мета. Створення якісних та безпечних умов праці щодо фактору шуму та забруднення відпрацьованими газами від автотранспорту, що рухається проспектом Д. Яворницького, для персоналу установ обслуговування на території громадського центру міста Дніпро.

Матеріали й методи. Шляхом натурних спостережень отримано дані про стан шумового режиму, рівень загазованості від автотранспорту та кількість робочих місць на дослідній території.

Результати. Рівні шумового забруднення за два метри від фасадів будинків першого ешелону забудови по просп. Д. Яворницького коливаються від 72 дБА до 75 дБА. Концентрація відпрацьованих газів коливається в межах 1535 мг $/ \mathbf{M}^{3}$. Встановлено, що на території центру знаходиться 6000 м² торгівельних площ соціально-побутових об'єктів, на яких працюють 330 осіб різних професій.

Висновки. Розглянуто динаміку змін транспортного навантаження на пр. Д. Яворницького з 2011 по 2017 роки. Встановлено, що еквівалентний рівень шуму перевищує допустиму норму на робочих місцях на 9-19 дБА, а концентрація $\mathrm{C}_{\mathrm{CO}}-$ на $15-30 \mathrm{Mг} / \mathrm{m}^{3}$.

Ключові слова: громадський центр міста, транспортне навантаження, об’єкти обслуговування, робочі місця.

П.Н. Саньков, Н.А. Ткач, К.Б. Дикарев, А.Н. Близнюк, Б.Д. Гваджаиа

ГВУЗ «Приднепровская государственная академия строительства и архитектуры», ул. Чернышевского, 24а, Днепр, 49005, Украина, +3805624523 72, +38056247 0788, postmaster@pgasa.dp.ua

\title{
ВЛИЯНИЕ АВТОТРАНСПОРТА НА РАБОЧИЕ МЕСТА В СЕТИ УЧРЕЖДЕНИЙ ОБСЛУЖИВАНИЯ (ПО ФАКТОРУ ШУМА И ЗАГАЗОВАННОСТИ В ЦЕНТРЕ ГОРОДА ДНЕПР)
}

Введение. В статье рассмотрены основные положения по реализации конституционного права работников на охрану их жизни и здоровья в процессе трудовой деятельности, на надлежащие и безопасные условия труда, а также вопросы регуляции с участием соответствующих органов государственной власти отношений между работодателем и работником по вопросам безопасности, гигиены труда и производственной среды и установления единого порядка организации охраны труда в Украине. 
Проблематика. Анализ проблем развития современного общественного центра как сети учреждений обслуживания с учетом состояния безопасности труда на рабочих местах.

Цель. Создание качественных и безопасных условий труда по факторам шума и загрязнения отработанными газами от автотранспорта, движущегося по проспекту Д. Яворницкого, для персонала учреждений обслуживания на территории общественного центра города Днепр.

Материалы и методы. Путем натурных наблюдений получены данные о состоянии шумового режима, загазованности от автотранспорта и количества рабочих мест на исследуемой территории.

Результаты. Уровни шумового загрязнения в двух метрах от фасадов зданий первого эшелона застройки по просп. Д. Яворницкого колеблются от 72 дБА до 75 дБА. Концентрация отработанных газов колеблется в пределах от 15 до 35 мг $/ \mathrm{M}^{3}$. Установлено, что на территории центра находится $6000 \mathrm{~m}^{2}$ торговых площадей социально-бытовых объектов, на которых работает 330 человек разных профессий.

Выводы. Рассмотрена динамика изменений транспортной нагрузки на пр. Д. Яворницкого с 2011 по 2017 годы. Установлено, что эквивалентный уровень шума превышает допустимую норму на рабочих местах на 9-19 дБА, а концентрация $\mathrm{C}_{\mathrm{CO}}-$ на $15-30$ мг $\mathrm{M}^{3}$.

Ключевые слова: общественый центр города, транспортная нагрузка, объекты обслуживания, рабочие места. 